Table 1 Transition probabilities in respondent heterogeneity, controlled by educational level

\begin{tabular}{|c|c|c|c|c|c|c|c|c|}
\hline \multirow[b]{3}{*}{ Item } & \multicolumn{8}{|c|}{ Response categories } \\
\hline & \multicolumn{2}{|c|}{ DT } & \multicolumn{2}{|c|}{$\mathrm{D}$} & \multicolumn{2}{|c|}{$\mathrm{C}$} & \multicolumn{2}{|c|}{ CT } \\
\hline & Low & High & Low & High & Low & High & Low & High \\
\hline $\begin{array}{l}\text { I am more concerned with getting COVID-19 than concerned with } \\
\text { the possibility of others getting it. }\end{array}$ & 0.46 & 0.42 & 0.41 & 0.54 & 0.01 & 0.00 & 0.12 & 0.04 \\
\hline $\begin{array}{l}\text { I'm more concerned with the people around me getting COVID-19 } \\
\text { than myself** }\end{array}$ & 0.08 & 0.08 & 0.39 & 0.63 & 0.02 & 0.02 & 0.51 & 0.27 \\
\hline Much of what is said about COVID-19 is fake. & 0.69 & 0.61 & 0.23 & 0.37 & 0.00 & 0.00 & 0.09 & 0.02 \\
\hline People are exaggerating the measures taken against COVID-19. & 0.69 & 0.62 & 0.25 & 0.35 & 0.01 & 0.00 & 0.05 & 0.03 \\
\hline $\begin{array}{l}\text { I didn't change my routine because of COVID-19, since where I live, } \\
\text { it doesn't exist.* }\end{array}$ & 0.02 & 0.06 & 0.18 & 0.47 & 0.01 & 0.03 & 0.79 & 0.44 \\
\hline $\begin{array}{l}\text { I have a hard time following the recommendations against COVID- } \\
19 \text { because they harm me at work.* }\end{array}$ & 0.57 & 0.63 & 0.22 & 0.30 & 0.01 & 0.00 & 0.20 & 0.06 \\
\hline $\begin{array}{l}\text { Following the recommendations against COVID-19 is a problem, as } \\
\text { I need to help one or more people outside my home.* }\end{array}$ & 0.03 & 0.05 & 0.12 & 0.19 & 0.10 & 0.50 & 0.74 & 0.26 \\
\hline $\begin{array}{l}\text { It is tough for me to follow the recommendations against COVID-19, } \\
\text { as I have a disease, and I need to treat myself outside my home.* }\end{array}$ & 0.00 & 0.04 & 0.02 & 0.16 & 0.05 & 0.41 & 0.94 & 0.39 \\
\hline $\begin{array}{l}\text { I've been losing (or making less) money since the COVID-19 } \\
\text { pandemic.* }\end{array}$ & 0.00 & 0.03 & 0.02 & 0.17 & 0.13 & 0.59 & 0.84 & 0.22 \\
\hline $\begin{array}{l}\text { I have suffered a lot from not meeting with my family and friends } \\
\text { because of the COVID-19 pandemic.* }\end{array}$ & 0.01 & 0.11 & 0.13 & 0.23 & 0.10 & 0.45 & 0.76 & 0.22 \\
\hline $\begin{array}{l}\text { I am very concerned about people in my family or friends who are at } \\
\text { risk for COVID-19.* }\end{array}$ & 0.01 & 0.03 & 0.00 & 0.13 & 0.05 & 0.34 & 0.94 & 0.50 \\
\hline I am very concerned because I am a risk group for COVID- 19 . & 0.61 & 0.78 & 0.14 & 0.13 & 0.09 & 0.06 & 0.15 & 0.03 \\
\hline
\end{tabular}

$\mathrm{C}=$ agree; $\mathrm{CT}$ = agree completely; $\mathrm{D}=$ disagree; DT = disagree completely; High = profile with a higher level of consciousness; Low = profile with a lower level of consciousness).

Bold type denotes significant differences among transition probabilities.

* Items impacted by educational level.

traits associated with engagement with containment measures? Trends Psychiatry Psychother. 2020;42:179-84.

4 Bray BC, Smith RA, Piper ME, Roberts LJ, Baker TB. Transitions in smokers' social networks after quit attempts: a latent transition analysis. Nicotine Tob Res. 2016;18:2243-51.

5 Collins LM, Lanza ST. Latent class and latent transition analysis: with applications in the social, behavioral and health sciences. New York: Wiley \& Sons; 2010.

\section{Which is the best way of using nitrous oxide for treatment and research in neuropsychiatry?}

Braz J Psychiatry. 2021 Jul-Aug;43(4):448-449 doi:10.1590/1516-4446-2021-1879

(cc) BY-NC

I welcome the excellent paper by Guimarães et al. ${ }^{1}$ which extends research on nitrous oxide $\left(\mathrm{N}_{2} \mathrm{O}\right)$ in neuropsychiatry - a neglected field, since our initial work in 1982 and then $1985^{2}$ indicating that low, anxiolytic, and non-anaesthetic doses of $\mathrm{N}_{2} \mathrm{O}$ ameliorate depression. ${ }^{3}$ Research has demonstrated that $\mathrm{N}_{2} \mathrm{O}$, at subanaesthetic concentrations acts on opioid receptors. ${ }^{2,3}$ We therefore concluded that the antidepressant activity of $\mathrm{N}_{2} \mathrm{O}$ occurred via opioid activity. ${ }^{2,3}$

Interestingly, this latest work ${ }^{1}$ confirms our findings that the antidepressant action of $\mathrm{N}_{2} \mathrm{O}$ occurred immediately and endured after gas administration. ${ }^{2,3}$ It also supports our unpublished observation that the gas could be used as an adjuvant to routine antidepressant medication. ${ }^{2,3}$

Like Nagele's group, ${ }^{1}$ Guimarães et al. ${ }^{1}$ believe that $\mathrm{N}_{2} \mathrm{O}$ and ketamine are antidepressant mainly via antagonism of the $\mathrm{N}$-methyl-D-aspartate receptor (NMDAr). However, they provide two key references disputing NMDAr involvement. ${ }^{1}$ One showed that naloxone blocks the antidepressant action of ketamine, and the other that NMDAr antagonists (like memantine) are not antidepressant. ${ }^{1}$ These references and our work ${ }^{2,3}$ indicate that opioid receptors are more likely to be responsible for the antidepressant action of $\mathrm{N}_{2} \mathrm{O}$ and ketamine. Indeed, NMDAr blockade occurs only at $\mathrm{N}_{2} \mathrm{O}$ concentrations 
which are anaesthetic and not subanaesthetic, ${ }^{4}$ making it unlikely that the NMDAr mediates the antidepressant action observed. ${ }^{1,4}$

The dental technique (using identical equipment as here $^{1}$ ) never has a fixed goal-concentration, but titrates $\mathrm{N}_{2} \mathrm{O}$ using each individual's dose-response to reach concentrations achieving maximum relaxation while maintaining consciousness. In short, the concentration varies, depending on each individual's dose-response to $\mathrm{N}_{2} \mathrm{O}^{2,3}$ Apart from avoiding anaesthesia it also minimises side effects. $^{3}$

Because a relatively loose nasal mask was used without $\mathrm{N}_{2} \mathrm{O}$ end tidal measurements ${ }^{1}$ the inhaled gas concentration at the alveolus cannot be assumed. Thus, the reading of $50 \%$ on the rotameter alone is a poor reflection of the actual gas volume inhaled. ${ }^{3}$ Indeed, nasal masks produce $\mathrm{N}_{2} \mathrm{O}$ concentrations at the alveolus which are less than half the rotameter setting. ${ }^{3}$

Guimaraes et al chose $50 \% \mathrm{~N}_{2} \mathrm{O}$ mistakenly believing that it produces minimal sedation and refer to the American Anesthesiology Association Guidelines. ${ }^{1,5}$ These guidelines clearly states: "less than $50 \%$ " $\mathrm{N}_{2} \mathrm{O}$ is required to produce minimal sedation, which encompasses the dental titration method. $^{3}$ Since a fixed goal concentration ignores the individual sensitivities to the gas, it is unsurprising that they "could find no data" giving the "best concentration of $\mathrm{N}_{2} \mathrm{O}$ "1 for depression. Perhaps, this indicates that the correct antidepressant dose is best achieved by titrating, to each individual's requirements, without an anaesthetist. ${ }^{2-5}$

Mark A. Gillman iD South African Brain Research Institute, Johannesburg, Gauteng, South Africa.

Submitted Mar 15 2021, accepted Mar 29 2021, Epub May 102021.

\section{Disclosure}

MAG has been researching the psychotropic properties of nitrous oxide for over 40 years. Since 2003 he has been a medical adviser to Sedatek, a South African company that supplies equipment for nitrous oxide in South Africa, predominantly among dentists; he owns no shares in the company.

How to cite this article: Gillman MA. Which is the best way of using nitrous oxide for treatment and research in neuropsychiatry? Braz J Psychiatry. 2021;43:448-449. http://dx.doi.org/10.1590/1516-44462021-1879

\section{References}

1 Guimarães MC, Guimarães TM, Hallak JE, Abrão J, Machado-deSousa JP. Nitrous oxide as an adjunctive therapy in major depressive disorder: a randomized controlled double-blind pilot trial. Braz J Psychiatry. 2021 Feb 15:S1516-44462021005005201. doi: 10.1590/ 1516-4446-2020-1543. Epub ahead of print

2 Gillman MA, Matussek N, Lichtigfeld FJ. Effect of nitrous oxide on depressive patients and volunteers. In: Pichot $\mathrm{P}$, Berner $\mathrm{P}$, Wolf $\mathrm{R}$, Thau K. Biological psychiatry, higher nervous activity. Boston: Springer; 1985. p. 397-403.
3 Gillman MA. Mini-review: a brief history of nitrous oxide (N2O) use in neuropsychiatry. Curr Drug Res Rev. 2019;11:12-20.

4 Jevtović-Todorović V, Todorović SM, Mennerick S, Powell S, Dikranian $\mathrm{K}$, Benshoff $\mathrm{N}$, et al. Nitrous oxide (laughing gas) is an NMDA antagonist, neuroprotectant and neurotoxin. Nat Med. 1998;4:460-3.

5 American Society of Anesthesiologists Task Force on Sedation and Analgesia by Non-Anesthesiologists. Practice guidelines for sedation and analgesia by non-anesthesiologists. Anesthesiology. 2002;96: 1004-17.

\section{Development and analysis of the psychometric properties of the Fear of Childbirth Motivators Questionnaire (QMMP)}

Braz J Psychiatry. 2021 Jul-Aug;43(4):449-451

doi:10.1590/1516-4446-2021-1815

(cc) BY-NC

Pregnancy is a time of important physiological, aesthetic and psychosocial changes. ${ }^{1}$ The fear of childbirth is a common condition, involving 5 to $20 \%$ of women. ${ }^{2}$ Clinically, the pregnancy and puerperal period can be affected, increasing the preference for cesarean section on request. Brazil ranks as the second country in the world with the highest rate of cesarean sections $(57 \%){ }^{3}$ and the fear of childbirth is probably associated with many of these procedures. Using the recent published Tokophobia Assessment Questionnaire, objective identification of pregnant women with phobic fear of childbirth is possible in the Brazilian context. ${ }^{4}$ In addition, identifying factors which lead to this fear is important to guide and educate pregnant women and their families. However, in Brazil, there is no instrument that objectively evaluates this parameter, which makes it impossible to carry out assertive actions aimed at the Brazilian population. Thus, the Fear of Childbirth Motivators Questionnaire (Questionário de Motivadores do Medo do Parto, QMMP) was developed and validated specifically for the Brazilian sociocultural and clinical-obstetric context.

A cross-sectional study was conducted to estimate the reliability and validity of the proposed instrument. Pregnant women who attended prenatal consultations at a medical school clinic were included, and those with psychiatric conditions that made it difficult to understand the instrument or with absolute indications for cesarean section were excluded. A total sample of 266 patients was obtained. The guidelines for development and validation of the QMMP were supported by international recommendations. ${ }^{5}$ The psychometric properties were assessed using exploratory factor analysis (EFA).

Validity was assessed by applying an external instrument (the Penn State Worry Questionnaire) and the QMMP (Table 1) to 266 pregnant women. The QMMP was subsequently re-administered to 107 participants. 